\title{
Predictors of quality of life after moderate to severe traumatic brain injury
}

\author{
Preditores de qualidade de vida após trauma crânio-encefálico moderado a grave \\ Karina Tavares Weber', Viviane Assunção Guimarães', Octávio M Pontes-Neto 1,2, João P. Leite1, Osvaldo \\ Massaiti Takayanagui', Taiza E. G. Santos-Pontelli
}

\begin{abstract}
Objective: To verify correlations between age, injury severity, length of stay (LOS), cognition, functional capacity and quality of life (QOL) six months after hospital discharge (HD) of victims of traumatic brain injury (TBI). Method: 50 patients consecutively treated in a Brazilian emergency hospital were assessed at admission, HD and six months after HD. The assessment protocol consisted in Abbreviated Injury Scale, Injury Severity Score, Glasgow Coma Scale (GCS), Revised Trauma Score (RTS), Mini Mental Test, Barthel Index and World Health Organization QOL - Brief. Results: Strong negative correlation was observed between LOS and GCS and LOS and RTS. An almost maximal correlation was found between RTS and GCS and functional capacity and GCS at HD. Age and LOS were considered independent predictors of QOL. Conclusion: Age and LOS are independent predictors of QOL after moderate to severe TBI.
\end{abstract}

Keywords: brain injuries, epidemiology; quality of life.

\section{RESUMO}

Objetivo: Verificar correlações entre idade, gravidade do trauma, tempo de hospitalização (TH), cognição, capacidade funcional e qualidade de vida (QV) seis meses após alta hospitalar (AH) de vítimas de trauma crânio-encefálico (TCE). Método: 50 pacientes tratados em um hospital de emergência brasileiro foram avaliados na admissão, AH e seis meses após AH. O protocolo de avaliação consistia em Escala Abreviada de Lesões, Índice de Gravidade de Lesão, Escala de Coma de Glasgow (ECG), Escore de Trauma Revisado (RTS), teste Mini-Mental, Índice de Barthel e Questionário Breve de QV da Organização Mundial de Saúde. Resultados: Forte correlação negativa foi observada entre TH e ECG e TH e RTS. Correlação quase máxima foi observada entre RTS e ECG e capacidade funcional e ECG na AH. Idade e TH foram considerados preditores independentes de QV. Conclusão: Idade e TH são preditores independentes de QV após TCE moderado e grave.

Palavras-chave: traumatismos encefálicos, epidemiologia; qualidade de vida.

Trauma is considered a disease of varied aetiology and corresponds to the third cause of death worldwide, surpassed only by cardiovascular diseases and neoplasms ${ }^{1}$. In Brazil, it affects about one million people per year, 360,000 of them have some impairment or disability, and 120,000 of them don't survive 2 .

Among the types of trauma, traumatic brain injury (TBI) stand out as the most important cause of disability among young people and a common cause of neurologic morbidity. It represents a serious public health problem with high socio-economic costs related to mortality, morbidity and disability $^{3}$. TBI is also considered a "silent epidemic" because the vast majority oflong-term disabilities remains underestimated ${ }^{4}$.
At present, TBI is an important public health problem worldwide and traffic accidents are among the leading causes of disability and premature death. In 2005, the USA had, due to traffic accidents, a mortality rate of 29.7/100,000 inhabitants, while in European countries, the problem exists to a lesser extent: Germany presents rate of 10.5/100,000 inhabitants and Netherlands, 8.4/100,000 inhabitants ${ }^{5}$. According to the World Health Organization (WHO), in South America countries, increasing annual numbers of traffic accidents contribute an alarming compromise of quality of life (QOL) in those populations ${ }^{5}$.

However, there are very few epidemiological studies about TBI in developing countries ${ }^{6}$. Especially in Brazil,

1Universidade de São Paulo, Faculdade de Medicina, Departamento de Neurociências e Ciências do Comportamento, Ribeirão Preto SP, Brasil;

${ }^{2}$ Harvard Medical School, Massachusetts General Hospital, Department of Neurology, Boston MA, United States.

Correspondence: Taiza E. G. Santos-Pontelli; Departamento de Neurociências e Ciências do Comportamento, Faculdade de Medicina de Ribeirão Preto, Universidade de São Paulo; Av. dos Bandeirantes, 3900; 14049-900 Ribeirão Preto SP, Brasil. E-mail: taiza@fmrp.usp.br

Conflict of interest: There is no conflict of interest to declare.

Support: This work was supported by funds from the Coordenaçao de Aperfeiçoamento de Pessoal de Nivel Superior - Brazil.

Received 2 September 2015; Received in final form 14 December 2015; Accepted 15 March 2016. 
the few studies available have focused on hospital mortality and use of hospital resources. There are very few data about the dysfunction and impact of QOL after a TBI in Brazil7. Only a few small studies in Brazil have applied instruments to assess QOL in the population with $\mathrm{TBI}^{8}$, making it difficult to evaluate which aspects may influence the outcomes of those patients. Moreover, as pointed out by some authors, patient-centred outcome research may increase our ability to translate that information into public policies for prevention, treatment and rehabilitation for $\mathrm{TBI}^{9}$.

This study was designed to evaluate patients after TBI admitted to a public tertiary trauma centre in Brazil and to identify predictors of functional capacity and QOL six months after their hospital discharge.

\section{METHOD}

The Ethics Committee of Clinics Hospital - Faculdade de Medicina de Ribeirão Preto - Universidade de São Paulo approved this study. Written informed consent forms were obtained from all patients or legally authorized representative.

This is a longitudinal and descriptive study conducted at the emergency unit of a public university hospital, which is a tertiary referral centre for the care of TBI at Ribeirão Preto and its metropolitan area.

We evaluated 50 survivals of moderate to severe TBI, aged over 18 years who were consecutively discharged from the neurology ward of a tertiary emergency and agreed to participate in the study. The exclusion criteria were terminal illness with life expectancy less than one year determined by the medical provider; previous neurological disease with significant functional impairment and prognostic impact and cognitive inability to fill out the questionnaire administered.

Clinical evaluation was performed in three distinct stages: admission, hospital discharge and six months after hospital discharge. The data from admission were collected retrospectively from the hospital-based registry. The data from hospital discharge and six months after the hospital discharge were collected prospectively.

At admission, anatomical and physiological trauma scores were used to assess the severity of the injury and to define the extent of injury ${ }^{2,10}$. The physiological scores used were Glasgow Coma Scale (GCS) and Revised Trauma Score (RTS). The anatomical score used was the Injury Severity Score (ISS).

Upon hospital discharge, demographic data, the GCS, Mini Mental Test and Barthel Index were assessed. After six months of hospital discharge, a single home visit was performed to evaluate GCS, Mini Mental Test, Barthel Index and QOL.

The QOL of patients with TBI was evaluated by World Health Organization Quality Of Life - brief(WHOQOL-brief), an instrument recognized worldwide that is easy to use and understand, available and validated in Brazil ${ }^{11}$.
It was emphasized that the questionnaire refers to the conditions of life in the last two weeks, regardless of where the individual was living. The interviewer didn't influence the patient's response nor discussed the issues or answers. If there were any questions while filling out the questionnaire administered, the interviewer read back the questions, avoiding synonymous to prevent interference with the response of the patient.

The reliability of the factors was determined by assessing the internal consistency of each one by the Cronbach's alpha technique. A factor was considered accurate if the minimum index of internal consistency was equal to or greater than $0.80^{12}$.

\section{Data and statistical analysis}

The data were analysed using Statistical Package for the Social Sciences (SPSS) version 20.0 for Mac. The calculations of the WHOQOL-brief questionnaire were performed according to the official site: http://www.ufrgs.br/psiquiatria/psiq/whoqol4.html.

Categorical variables are described using absolute and relative frequency, and the Chi-square test was used to verify potential associations among the variables. Comparisons between the results of three or more related samples (average posts) were made using a Friedman ANOVA test (paired samples). The Wilcoxon test was used if there were no significant differences between the means. This test also assessed whether there were significant differences between mean positions for two groups while comparisons between mean positions for more than two groups were made using the Kruskal-Wallis test. The Spearman correlation coefficient was used to examine associations between variables. The Cohen's (1988) conventions were used to interpret effect size. A correlation coefficient of 0.10 was considered a weak or small association; a correlation coefficient of 0.30 was considered a moderate correlation, and a correlation coefficient of 0.50 or larger was considered a high correlation. When appropriately related to relevant hypotheses of the present study, the variables with statistically significant correlation were included in linear regression analysis. The level of significance was set at $5 \%(p<0.05)$.

\section{RESULTS}

50 patients discharged from the neurological ward with moderate to severe TBI in the study period were included. They were in agreement with our inclusion/exclusion criteria. Table 1 describes the demographic and socioeconomic data of the patients.

Table 2 shows the general causes of TBI and according to age groups. Most motor vehicle accidents and cases of interpersonal violence in this study composed by victims of physical abuse (beatings) and injury by firearms occurred in younger age groups, while falls were the most common among the elderly. The presence of falls in younger age groups was small and was associated with the use of alcohol (6\%), neurological convulsing diseases (2\%), accidents (4\%) and eventual fall (4\%). 
Table 1. The distribution of victims according to demographic and education data.

\begin{tabular}{|c|c|c|}
\hline Variables & Number & $\%$ \\
\hline \multicolumn{3}{|l|}{ Gender } \\
\hline Male & 44 & 88 \\
\hline Female & 6 & 12 \\
\hline \multicolumn{3}{|l|}{ Race/ethnicity } \\
\hline White & 44 & 88 \\
\hline Black & 3 & 6 \\
\hline Mullato & 3 & 6 \\
\hline \multicolumn{3}{|l|}{ Age (years) } \\
\hline $18-25$ & 14 & 28 \\
\hline $26-35$ & 11 & 22 \\
\hline $36-45$ & 10 & 20 \\
\hline $45-55$ & 4 & 8 \\
\hline $56-65$ & 6 & 12 \\
\hline 66 or older & 5 & 10 \\
\hline \multicolumn{3}{|l|}{ Education } \\
\hline Illiterate & 3 & 6 \\
\hline Incompleted primary & 8 & 16 \\
\hline Completed primary & 8 & 16 \\
\hline Incompleted gymnasium & 11 & 22 \\
\hline Completed gymnasium & 2 & 4 \\
\hline Incompleted high school & 7 & 14 \\
\hline Completed high school & 10 & 20 \\
\hline Incompleted college & 1 & 2 \\
\hline
\end{tabular}

Regarding the injured body area, it was observed that $100 \%$ of the victims showed nonspecific lesions beyond the TBI as abrasions, contusions and generalized lacerations that can't be considered a single piece body.

Concerning primary lesions arising TBI, there were observed skull fractures (22\%), contusions (48\%), diffuse axonal injury (26\%), intraparenchymal hematoma (4\%), subdural hematoma (30\%), extradural hematoma (16\%) and other minor injuries (12\%) while in secondary lesions there was observed the brain swelling (38\%). Haemorrhage was found in $24 \%$ of the victims being the intraparenchymal the most frequent followed by the arachnoid.

The length of hospitalization ranged from 02 to 133 days (median $=18.5$ days), $50 \%$ of patients required admission to the intensive care unit (ICU) (mean $=15.84$ SD 9.78 days) and $60 \%$ required mechanical ventilation $(\mathrm{MV})($ mean $=7.7 \mathrm{SD}$ 4.74 days). In accidents involving private cars and motorcycles, the use of MV was required in $84 \%$ of cases, and $72 \%$ of these were admitted to the ICU. Of the patients undergoing MV, 16 (64\%) underwent tracheotomy procedure and of these, 11 (68.75\%) were discharged with tracheotomy.

According ISS, the most frequent injury classification was moderate (48\%), followed by mild trauma (38\%) and severe trauma (14\%). The variation in scoring ISS was 5 to 35 , and the mean value of $17.60 \pm 8.62$. Table 3 shows the results of the anatomical and functional scales according to age groups (group A: 18-85 years old; group B: 18-25 years old; group
Table 2. The distribution of victims according to demographic and etiological data.

\begin{tabular}{|c|c|c|}
\hline Variables & number & $\%$ \\
\hline \multicolumn{3}{|l|}{ Causes of TBI } \\
\hline Automobile & 16 & 32 \\
\hline Fall & 12 & 24 \\
\hline Bike & 6 & 12 \\
\hline Running over & 6 & 12 \\
\hline Motorcycling & 3 & 6 \\
\hline Physical aggression & 6 & 12 \\
\hline Firearm & 1 & 2 \\
\hline \multicolumn{3}{|l|}{ Causes of TBI according to age group } \\
\hline \multicolumn{3}{|l|}{$15-25$ years old } \\
\hline Traffic accidents of motor vehicles & 10 & 20 \\
\hline Aggressions & 1 & 2 \\
\hline Accidental falls & 2 & 4 \\
\hline $\begin{array}{l}\text { Homicide and injuries caused intentionally } \\
\text { by others }\end{array}$ & 1 & 2 \\
\hline \multicolumn{3}{|l|}{$26-35$ years old } \\
\hline Traffic accidents of motor vehicles & 9 & 18 \\
\hline Aggressions & 2 & 4 \\
\hline Accidental falls & 0 & 0 \\
\hline $\begin{array}{l}\text { Homicide and injuries caused intentionally } \\
\text { by others }\end{array}$ & 0 & 0 \\
\hline \multicolumn{3}{|l|}{$36-45$ years old } \\
\hline Traffic accidents of motor vehicles & 5 & 10 \\
\hline Aggressions & 2 & 4 \\
\hline Accidental falls & 3 & 6 \\
\hline $\begin{array}{l}\text { Homicide and injuries caused intentionally } \\
\text { by others }\end{array}$ & 0 & 0 \\
\hline \multicolumn{3}{|l|}{$46-55$ years old } \\
\hline Traffic accidents of motor vehicles & 3 & 6 \\
\hline Aggressions & 1 & 2 \\
\hline Accidental falls & 0 & 0 \\
\hline $\begin{array}{l}\text { Homicide and injuries caused intentionally } \\
\text { by others }\end{array}$ & 0 & 0 \\
\hline \multicolumn{3}{|l|}{$56-65$ years old } \\
\hline Traffic accidents of motor vehicles & 2 & 4 \\
\hline Aggressions & 3 & 6 \\
\hline Accidental falls & 0 & 0 \\
\hline $\begin{array}{l}\text { Homicide and injuries caused intentionally } \\
\text { by others }\end{array}$ & 0 & 0 \\
\hline \multicolumn{3}{|l|}{66 - 85 years old } \\
\hline Traffic accidents of motor vehicles & 2 & 4 \\
\hline Aggressions & 0 & 0 \\
\hline Accidental falls & 4 & 8 \\
\hline $\begin{array}{l}\text { Homicide and injuries caused intentionally } \\
\text { by others }\end{array}$ & 0 & 0 \\
\hline \multicolumn{3}{|l|}{ Other lesions } \\
\hline Head & 50 & 100 \\
\hline Face & 15 & 30 \\
\hline Neck & 1 & 2 \\
\hline Chest & 11 & 22 \\
\hline Column & 4 & 8 \\
\hline Abdomen & 7 & 14 \\
\hline Upper limbs & 14 & 28 \\
\hline Lower limbs & 10 & 20 \\
\hline Pelvis & 1 & 2 \\
\hline
\end{tabular}

TBI: traumatic brain injury. 
C: 26-35 years old; group D: 36-45 years old; group E: 45-55 years old; group F: 56-65 years old; group G: 66-85 years old).

At admission, $52 \%$ of the victims had a GCS score $\leq 8$ (severe TBI), whereas $80.8 \%$ of these were admitted to the ICU, while mild trauma accounted for $36 \%$ of the patients studied. In each case, the most common mechanism of injury was the motor vehicle accidents (40\%) and falls (18\%), respectively.

Strong negative correlation was observed between length of stay (LOS) in hospital and GCS (Spearman correlation, $\mathrm{p}<0.001, \mathrm{r}=-0.709$ ). The causal relationship between these variables was confirmed by linear regression analysis $(\mathrm{p}<0.001, \mathrm{r} 2=0.32)$ (Figure 1$)$.

The mean RTS in the study population was $6.33 \pm 1.30$ (Min = 4.09; $\operatorname{Max}=7.84$ ). There was a strong negative correlation with statistical significance between LOS and RTS (Spearman correlation, $\mathrm{p}<0.001, \mathrm{r}=-0.701$ ). A linear regression analysis confirmed the causal relationship and it is shown in Figure 2 (Linear Regression, $\mathrm{p}<.001, \mathrm{r} 2=0.28$ ).

A linear regression analysis shown in Figures 1 and 2 demonstrates that the one-point increase in GCS promotes, on average,

Table 3. Results of the anatomical and functional scales according to age groups.

\begin{tabular}{|c|c|c|c|c|c|c|c|c|}
\hline \multirow{4}{*}{$\begin{array}{l}\text { Groups } \\
\text { (age range) }\end{array}$} & \multirow{4}{*}{$\begin{array}{c}\text { Number } \\
\text { of } \\
\text { subjects }\end{array}$} & \multirow{3}{*}{$\frac{\text { ISS admission }}{\text { mean } \pm \text { SD }}$} & \multirow{3}{*}{$\frac{\text { RTS admission }}{\text { mean } \pm S D}$} & \multirow{2}{*}{$\begin{array}{l}\text { Glasgow } \\
\text { admission }\end{array}$} & \multicolumn{2}{|r|}{$\mathrm{BI}$} & \multicolumn{2}{|c|}{ MMSE } \\
\hline & & & & & \multirow{2}{*}{$\begin{array}{l}\text { discharge } \\
\text { mean } \pm S D\end{array}$} & \multirow{2}{*}{$\begin{array}{l}6 \text { months } \\
\text { mean } \pm S D\end{array}$} & \multirow{2}{*}{$\begin{array}{l}\text { discharge } \\
\text { mean } \pm S D\end{array}$} & \multirow{2}{*}{$\begin{array}{l}6 \text { months } \\
\text { mean } \pm S D\end{array}$} \\
\hline & & & & median & & & & \\
\hline & & $(\min -\max )$ & $(\min -\max )$ & $(\min -\max )$ & $\begin{array}{c}\text { median } \\
(\min -\max )\end{array}$ & $\begin{array}{l}\text { median (min- } \\
\max )\end{array}$ & $(\min -\max )$ & $(\min -\max )$ \\
\hline \multirow{2}{*}{$\begin{array}{l}\text { Group A } \\
\text { (18-85 years) }\end{array}$} & \multirow{2}{*}{50} & $17.6 \pm 8.6$ & $6.3 \pm 1.3$ & 8 & $29.8 \pm 30.1$ & $83 \pm 30.2$ & $11.4 \pm 8.5$ & $23.2 \pm 7.2$ \\
\hline & & $(4-47)$ & $(7.8-4.0)$ & $(3-15)$ & $25(0-100)$ & $100(0-100)$ & $(0-27)$ & $(0-30)$ \\
\hline \multirow{2}{*}{$\begin{array}{l}\text { Group B } \\
\text { (18-25 years) }\end{array}$} & \multirow{2}{*}{14} & $19.7 \pm 5.6$ & $6.3 \pm 1.3$ & 8 & $29.2 \pm 23.4$ & $95.4 \pm 10.5$ & $15.4 \pm 9.3$ & $27.25 \pm 3.3$ \\
\hline & & $(10-30)$ & $(4.1-7.8)$ & $(3-15)$ & $30(0-65)$ & $100(65-100)$ & $(0-27)$ & $(21-30)$ \\
\hline \multirow{2}{*}{$\begin{array}{l}\text { Group C } \\
\text { (26-35 years) }\end{array}$} & \multirow{2}{*}{8} & $16.2 \pm 9.3$ & $6 \pm 1.5$ & 8 & $19.4 \pm 30.8$ & $64.3 \pm 41.6$ & $7.6 \pm 8.3$ & $18.7 \pm 9.7$ \\
\hline & & $(10-34)$ & $(4-7.8)$ & $(3-14)$ & $0(0-85)$ & $85(0-100)$ & $(0-17)$ & $(0-29)$ \\
\hline \multirow{2}{*}{$\begin{array}{l}\text { Group D } \\
\text { (36-45 years) }\end{array}$} & \multirow{2}{*}{12} & $21 \pm 12$ & $5.9 \pm 1.3$ & 7.5 & $33.75 \pm 33.5$ & $88.9 \pm 24,6$ & $9.9 \pm 6.7$ & $22.9 \pm 3.9$ \\
\hline & & $(5-47)$ & $(4-7.8)$ & $(3-14)$ & $27.5(0-100)$ & $100(25-100)$ & $(0-17)$ & $(17-28)$ \\
\hline \multirow{2}{*}{$\begin{array}{l}\text { Group E } \\
\text { (45-55 years) }\end{array}$} & \multirow[b]{2}{*}{5} & $17 \pm 1.73$ & $5.9 \pm 1.2$ & 6 & $38 \pm 36.8$ & $100 \pm 0$ & $13.2 \pm 9.3$ & $27 \pm 2.9$ \\
\hline & & $(14-18)$ & $(4.5-7.8)$ & $(5-15)$ & $20(0-80)$ & $100(100-100)$ & $(0-24)$ & $(23-30)$ \\
\hline \multirow{2}{*}{$\begin{array}{l}\text { Group F } \\
\text { (56-65 years) }\end{array}$} & \multirow[b]{2}{*}{6} & $13 \pm 6.6$ & $7.2 \pm 1$ & 13.5 & $40.8 \pm 29.1$ & $78 \pm 30.9$ & $13.3 \pm 7.4$ & $23 \pm 5$ \\
\hline & & $(5-22)$ & $(5.97-7.8)$ & $(7-15)$ & $35(10-85)$ & $100(35-100)$ & $(0-20)$ & $(16-28)$ \\
\hline \multirow{2}{*}{$\begin{array}{l}\text { Group G } \\
\text { (66-85 years) }\end{array}$} & \multirow{2}{*}{5} & $11.6 \pm 8.2$ & $7.2 \pm 0.6$ & 12 & $17 \pm 38$ & $45 \pm 50.7$ & $5.2 \pm 8.3$ & $14.3 \pm 15$ \\
\hline & & $(4-24)$ & $(6.6-7.8)$ & $(9-15)$ & $0(0-85)$ & $35(0-100)$ & $(0-19)$ & $(0-30)$ \\
\hline
\end{tabular}

MMSE: Mini mental state examination;RTS: Revised trauma score;BI:Barthel index;GCS:Glasgow coma scale;SD:Standard deviation; Min: Minimum; Max:Maximum.

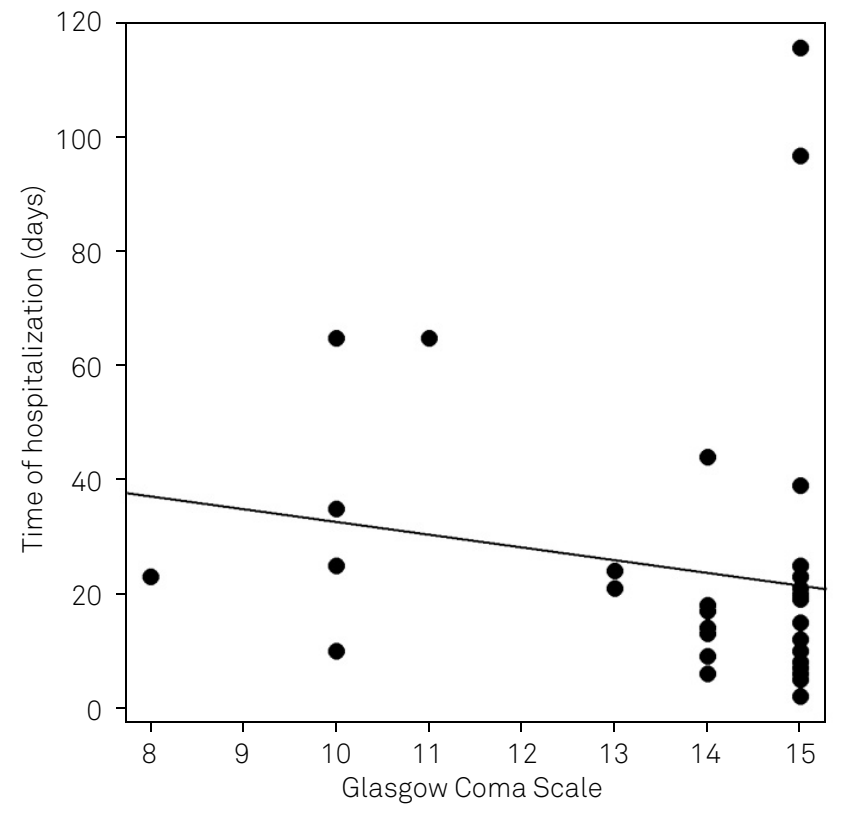

Figure 1. Linear regression analysis between the time of hospitalization and the Glasgow Coma Scale.

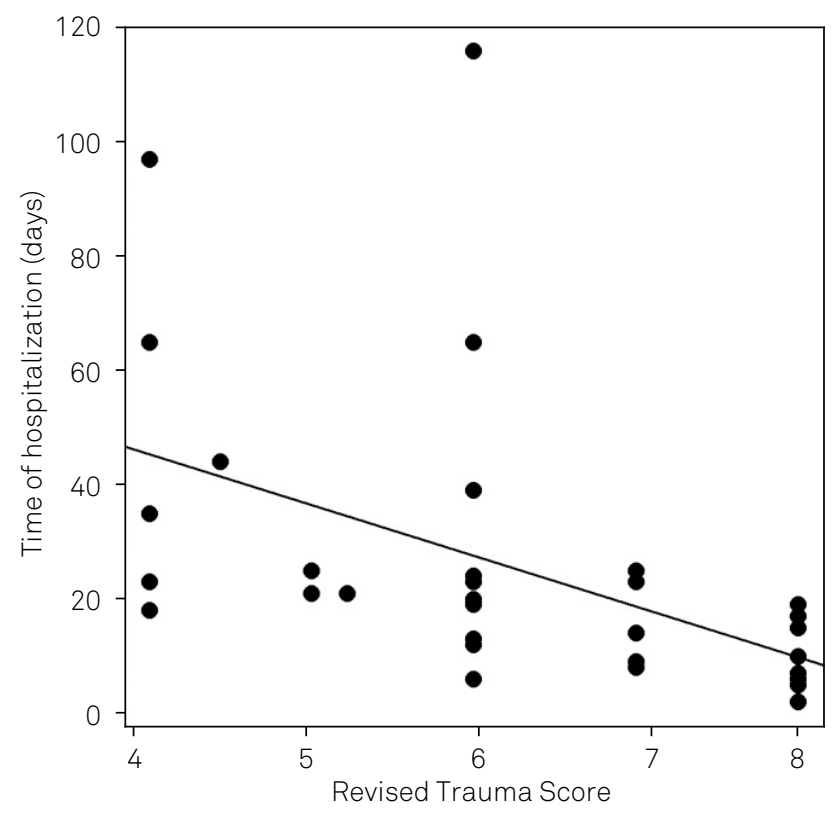

Figure 2. Linear regression analysis between the time of hospitalization and the Revised Trauma Score. 
a decrease of 4.11 days in LOS, whereas the decrease of one point in RTS promotes an increase of 11.86 days in LOS.

A correlation was observed almost maximal with strong statistical significance $(\mathrm{p}<0.001, \mathrm{r}=-0.969)$ in the analysis of Spearman correlation between the RTS and GCS variables.

As expected, there was a significant improvement in the activities of daily living function (ADL) observed by Barthel Index scores after six months of hospital discharge compared with the hospital discharge scores (mean =29.8 SD 30.1 and mean $=83.3$ SD 30.2, respectively; Wilcoxon Signed Ranks Test, $\mathrm{p}<0.001$ ). It was also observed strong statistically significant correlation between functional capacity and GCS at hospital discharge (Spearman correlation, $\mathrm{p}<0.001 \mathrm{r}=0.542$ ), as well as a moderate correlation of the ADL function at hospital discharge with both GCS and RTS (Spearman correlation, GCS: $p=0.005, r=0.45$; RTS: $p=0.01, r=0.41$ ).

QOL was assessed after six months of hospital discharge in 37 patients. Among the 13 excluded patients, five died, five were not found for an address change, and three showed no level of consciousness to participate in the interview $(\mathrm{GCS}<8)$.

The reliability of the four domains and facets was verified through analysis of internal consistency (Cronbach's alpha technique) and revealed that in all groups presented with a good level of internal consistency (higher than 0.8).

There was a moderate correlation between the cognitive state (Mini Mental test scores) with the physical and environmental domains of the WHOQOL-brief (physical domain: $\mathrm{p}=0.03, \mathrm{r}=0.35$; environmental domain $\mathrm{p}=0.02, \mathrm{r}=0.37$ ).

Table 4 shows the analyses of Spearman Correlation and Linear Regression of the WHOQOL-brief domains with age and length of stay. There was a moderate negative correlation of the psychological and environmental domains of the WHOQOL-brief with age (psychological domain: $p=0.04$, $r=-0.33$; environmental domain: $p=0.02, r=-0.36$ ), and the psychological and physical domains of the WHOQOL-brief with the LOS (psychological domain: $\mathrm{p}=0.02, \mathrm{r}=-0.37$; physical domain: $\mathrm{p}=0.01, \mathrm{r}=-0.42$ ). Further regression analysis suggested a causal relationship between those variables: psychological domain (age: $\mathrm{r} 2=0.11, \mathrm{p}=0.04$; LOS: $\mathrm{r} 2=0.14$, $\mathrm{p}=0.02$ ), physical domain (LOS: $\mathrm{r} 2=0.11, \mathrm{p}=0.04$ ) and environmental domain (age: $\mathrm{r} 2=0.15, \mathrm{p}=0.02$ ).

\section{DISCUSSION}

The relevance of this research is that it provides several epidemiological data and represents, to the best of our knowledge, the latest research on QOL with a significant sample size of patients with TBI after six months from hospital discharge developed in a Brazilian institution. Recently, in northern of Brazil, QOL was evaluated six months after the TBI event, but the aim of this study was mainly descriptive ${ }^{13}$. Also, other studies assessed aspects of quality of care and QOL after discharge of overall patients with trauma ${ }^{1,7}$. A further relevance of the present study relies on the analysis of the predictor factors of QOL in this population and on the helpful discussion for designing future studies on QOL after TBI.

In this study, it was found that the characteristics of the victims are related to the mechanisms of trauma, in which young adults engage more frequently in high-speed motor vehicle accidents, while the elderly, in falls, which corroborates the literature ${ }^{14,15}$. Also, the physiological condition on RTS was similar to data from another study that found a score greater than six ${ }^{16}$. These higher scores, i.e. less severe lesions, can be explained by prevention campaigns of the competent bodies as mandatory use of safety equipment and guidelines regarding the risk of accidents caused by the combination of direction and alcohol consumption. However, these data should be weighted, because the determination of respiratory rate, one of the components of the RTS, is influenced by patients' age, mechanism of injury, and mechanical ventilation'. Moreover, we observed that the worst RTS' scores (values between three and four) were associated with motor vehicle accidents and the best (values above seven) with falls.

The severity of TBI analysed by both the GCS and the RTS was found as predictive factors for LOS. Although some studies don't consider the values of GCS and RTS as valid predictors of $\mathrm{LOS}^{17}$, most of the previous studies have observed that the GCS is a useful tool in prediction models of TBI outcomes $^{18,19}$. More recently, it was demonstrated that the motor component of the GCS together with pupillary reactivity provide a simple and feasible score to stratify the severity of patients with TBI, contributing to the early definition of prognosis and most appropriate intervention for neuroprotection ${ }^{20}$. Also, it was noted that the RTS has been assessed as

Table 4. Results of the correlation and linear regression analyses between the domains of WHOQOL-brief with age and length of stay.

\begin{tabular}{|c|c|c|c|c|c|c|c|}
\hline \multirow{2}{*}{ Dependent variable } & \multirow{2}{*}{$\begin{array}{c}\text { Independent } \\
\text { Variable }\end{array}$} & \multirow{2}{*}{$\begin{array}{l}\text { Spearman } \\
\text { Correlation } \\
\text { p-value (r) }\end{array}$} & \multicolumn{5}{|c|}{ Linear Regression } \\
\hline & & & $95 \% \mathrm{Cl}$ & Alpha & Beta & $p$-value & $\mathrm{R}^{2}$ \\
\hline \multirow{2}{*}{ Psychological domain } & Age & $0.04(0.33)$ & 0.14 to -0.01 & 15.61 & 0.33 & 0.04 & 0.11 \\
\hline & LOS & $0.02(0.37)$ & -0.91 to -0.01 & 17.41 & 0.80 & 0.02 & 0.14 \\
\hline \multirow{2}{*}{ Environmental domain } & Age & $0.02(0.36)$ & 0.12 to -0.01 & 16.30 & 0.06 & 0.02 & 0.15 \\
\hline & LOS & $p=0.17(-0.23)$ & NA & NA & NA & NA & NA \\
\hline \multirow{2}{*}{ Physical domain } & Age & $p=0.22(-0.20)$ & NA & NA & NA & NA & NA \\
\hline & LOS & $0.01(0.42)$ & -0.09 to -0.01 & 15.81 & 0.05 & 0.04 & 0.11 \\
\hline
\end{tabular}

Cl: confidence interval; LOS: length of stay; NA: not analyzed. 
a useful scale to predict mortality, trauma severity and LOS in patients with polytrauma ${ }^{21}$. Thus, the results of these assessments can directly determine the LOS.

Nowadays, many tools have been created with the aim of assessing the physical, mental and social-related QOL, and to evaluate the impact of a disease on this ${ }^{22}$. Within this reality, we decided to use the WHOQOL-brief because it is a free access instrument, available in twenty languages and have good psychometric qualities. More recently, a multidisciplinary expert group on TBI recommended the WHOQOL as a good patient-centred outcome measure for this population $^{23}$. Most recently, a systematic review of studies on QOL after TBI reported that WHOQOL-brief showed positive results, but further evidence is limited ${ }^{24}$.

Relevant findings of the present study were that age and LOS are predictors of perceived QOL. The relationship observed that the higher the age, the better the QOL perceived by the patient corroborates with other studies that emphasized the impact of normative perceptions while aging on health ${ }^{25}$. According to these authors, older adults with TBI may consider the changes in their health or their symptoms as consequences of the aging process, rather than being caused by their TBI. In contrast, younger adults have a satisfactory health and when compare themselves with their healthy and age-matched peers may be more capable of perceiving changes in their health.

The relationship observed that the higher the LOS, the worse the QOL can be explained by the fact that the LOS reflects the injury severity effects that are not well tapped by GCS or RTS, i.e., the LOS may be the result of several severity-related factors and, thus, directly influence the QOL. The LOS can also be an indicator of the seriousness of other comorbidities and/or concomitant injuries that affects the QOL negatively after the hospital discharge in patients with $\mathrm{TBI}^{26}$.
In the present study, the functional capacity wasn't correlated with QOL, which is contradictory to the results found previously ${ }^{27}$. It is likely that this difference may have occurred due to the restricted sample studied and may indicate the need to use more sensitive instruments such as Functional Independence Measure (FIM), the Glasgow Outcome Scale Extended (GOSE), and the Disability Rating Scale (DRS) ${ }^{23,28,29,30}$.

Limitations of this study must be borne in mind when interpreting these results and for designing future studies on QOL after TBI. Although the population with TBI admitted to our tertiary emergency hospital during the study period was large, analyses were limited to inpatients only from the neurology ward and capable of filling out the questionnaire administered six months after the hospital discharge, which restricted the sample size. Thus, our results may not apply to more cognitively impaired participants. Furthermore, the results found in our sample reflect the characteristics of the population admitted to the neurology ward. Therefore, findings may not generalize to those with mild TBI who do not receive inpatient care in the neurology ward, or to those with very severe TBI who are treated in long-term nursing facilities. Further investigation with a larger sample size and path analysis modelling is required. Besides, the use of sample with a homogeneous severity of TBI will provide better conditions to evaluate the impact of the traumatic event on QOL.

The present study represents a pioneering analysis of the QOL of patients who have suffered TBI in Ribeirao Preto and its administrative area, and shows the importance of trying to optimize assistance to the population victim of trauma not only in order to improve QOL, but also to reduce hospital costs. Consequently, our results and interpretations add one more factor in judging the cost-effectiveness of therapeutic strategies, and will contribute to future studies conducted at tertiary emergency units.

\section{References}

Costa CDS, Scarpelini S. Avaliação da qualidade do atendimento ao traumatizado através do estudo das mortes em um hospital terciário. Rev Col Bras Cir. 2012;39(4):249-54. doi:10.1590/S0100-69912012000400002

2.

Carvalho AO, Bez Júnior A. Caracterização das vítimas de trauma assistidas por um serviço de atendimento pré-hospitalar. Einstein. 2004;2(3):199-205

3. Shivaji T, Lee A, Dougall N, McMillan T, Stark C. The epidemiology of hospital treated traumatic brain injury in Scotland. BMC Neurology. 2014;14(1):2. doi:10.1186/1471-2377-14-2

4. Mclntyre A, Mehta S, Aubut J, Dijkers M, Teasell RW. Mortality among older adults after a traumatic brain injury: a meta-analysis. Brain Inj. 2013;27(1):31-40. doi:10.3109/02699052.2012.700086

5. Rocha GS, Schor N. Acidentes de motocicleta no município de Rio Branco: caracterização e tendências. Ciênc Saúde Coletiva 2013;18(3):721-31. doi:10.1590/S1413-81232013000300018

6. Melo JR, Silva RA, Moreira Júnior ED. Características dos pacientes com trauma cranioencefálico na cidade de Salvador, Bahia, Brasil. Arq Neuropsiquiatr. 2004;62(3A):711-4 doi:10.1590/S0004-282X2004000400027
7. Alves ALA, Salim FM, Martinez EZ, Passos ADC, De Carlo MMRP, Scarpelini S. Qualidade de vida de vítimas de trauma seis meses após a alta hospitalar. Rev Saúde Publ. 2009;43(1):154-60. doi:10.1590/S0034-89102009000100020

8. Silva SCF, Settervall CHC, Sousa RMC. Amnésia pós-traumática e qualidade de vida pós-trauma. Rev Esc Enferm USP. 2012;46(Esp):30-7. doi:10.1590/S0080-62342012000700005

9. Gabriel SE, Normand SLT. Getting the methods right: the foundation of patient-centered outcomes research. New Engl J Med. 2012;367(9):787-90. doi:10.1056/NEJMp1207437

10. Kondo Y, Abe T, Kohshi K, Tokuda Y, Cook EF, Kukita I. Revised trauma scoring system to predict in-hospital mortality in the emergency department: Glasgow Coma Scale, age, and systolic blood pressure score. Crit Care. 2011;15(4):R191. doi:10.1186/cc10348

11. Fleck MPA, Louzada S, Xavier M et al. Aplicação da versão em português do instrumento WHOQOL-bref. Rev Saúde Pública. 2000;34(2):178-83. doi:10.1590/S0034-89102000000200012

12. Fukuda CC, Pasquali L. Professor eficaz: um instrumento de aferição. Aval Psicol. 2002;1(1):1-16. 
13. Vieira RCA, Hora EC, Oliveira DV, Ribeiro MCO, Sousa RMC. Quality of life of victims of traumatic brain injury six months after the trauma. Rev Lat Am Enferm. 2013;21(4):868-75. doi:10.1590/S0104-11692013000400006

14. Utomo WK, Gabbe BJ, Simpson PM, Cameron, PA. Predictors of in-hospital mortality and 6-month functional outcomes in older adults after moderate to severe traumatic brain injury. Injury. 2009;40(9):973-7. doi:10.1016/j.injury.2009.05.034

15. Cartaxo CKA, Nunes MS, Raposo OFF, Fakhouri R, Hora EC. Fall-related traumas in urgent care centers. Clinics. 2012;67(10):1133-8. doi:10.6061/clinics/2012(10)03

16. Batista SEA, Baccani JG, Silva RAP, Gualda KPF, Vianna RJA. Análise entre os mecanismos de trauma, as lesões e o perfil de gravidade das vítimas em Catanduva-SP. Rev Col Bras Cir. 2006;33(1):6-10. doi:10.1590/S0100-69912006000100003

17. Shah S, Muncer S. A comparison of rehabilitation outcome measures for traumatic brain injury. OTJR (Thorofare N J). 2003;23(1):2-9. doi:10.1177/153944920302300101

18. McNett M. A review of the predictive ability of Glasgow Coma Scale scores in head-injured patients. J Neurosci Nurs. 2007;39(2):68-75. doi:10.1097/01376517-200704000-00002

19. Duncan R, Thakore S. Decreased Glasgow coma scale score does not mandate endotracheal intubation in the emergency department. J Emerg Med. 2009;37(4):451-5. doi:10.1016/j.jemermed.2008.11.026

20. Hoffmann M, Lefering R, Rueger JM, Kolb JP, Izbicki JR, Ruecker AH et al. Trauma Registry of the German Society for Trauma Surgery: pupil evaluation in addition to Glasgow coma scale components in prediction of traumatic brain injury and mortality. Braz J Surg. 2012;99(S1):122-30. doi:10.1002/bjs.7707

21. Sloan EP, Koenigsberg M, Clark JM, Desai A. The use of the Revised Trauma Score as an entry criterion in traumatic hemorrhagic shock studies: Data from the DCLHb Clinical Trials. Prehospital Disaster Med. 2012;27(4):330-44. doi:10.1017/S1049023X12000970

22. Diaz AP, Schwarzbold ML, Thais ME, Hohl A, Bertotti MM, Schmoeller $R$ et al. Psychiatric disorders and health-related quality of life after severe traumatic brain injury: a prospective study. J Neurotrauma. 2012;29(6):1029-37. doi:10.1089/neu.2011.2089

23. Ardolino A, Sleat G, Willett K. Outcome measurements in major trauma - Results of a consensus meeting. Injury. 2012;43(10):1662-6. doi:10.1016/j.injury.2012.05.008

24. Polinder S, Haagsma JA, Klaveren D, Steyerberg EW, Beeck EF. Health-related quality of life after TBI: a systematic review of study design, instruments, measurement properties, and outcome. Popul Health Metr. 2015;13(1):4. doi:10.1186/s12963-015-0037-1

25. Breed ST, Flanagan SR, Watson KR. The relationship between age and the self-report of health symptoms in persons with traumatic brain injury. Arch Phys Med Rehabil. 2004;85 Suppl 2:S61-7. doi:10.1016/j.apmr.2003.08.115

26. Cuthbert JP, Corrigan JD, Harrison-Felix C, Coronado V, Dijkers MP, Heinemann AW. Factors that predict acute hospitalization discharge disposition for adults with moderate to severe traumatic brain injury. Arch Phys Med Rehabil. 2011;92(5):721-30. doi:10.1016/j.apmr.2010.12.023

27. Scholten AC, Haagsma JA, Andriessen TM, Vos PE, Steyerberg EW, Beeck EF, Polinder S. Health-related quality of life after mild, moderate and severe traumatic brain injury: patterns and predictors of suboptimal functioning during the first year after injury. Injury. 2015;46(4):616-24. doi:10.1016/j.injury.2014.10.064

28. Pretz CR, Dams-O'Connor K. Longitudinal description of the GOS-E for individuals in the traumatic brain injury model systems national database: a national institute on disability and rehabilitation research traumatic brain injury model systems study. Arch Phys Med Rehabil. 2013;94(12):2486-93. doi:10.1016/j.apmr.2013.06.02

29. Pretz CR, Malec JF, Hammond FM. Longitudinal description of the Disability Rating Scale for individuals in the national institute on disability and rehabilitation research traumatic brain injury model systems national database. Arch Phys Med Rehabil. 2013;94(12):2478-85. doi:10.1016/j.apmr.2013.06.019

30. Shukla D, Devi BI, Agrawal A. Outcome measures for traumatic brain injury. Clin Neurol Neurosur. 2011;113(6):435-41. doi:10.1016/j.clineuro.2011.02.013 